\title{
STUDY OF PERMEABILITY OF GLASS-SAND SOIL
}

\author{
F. C. WANG ${ }^{1}$, X. N. FENG ${ }^{2}$, H. GONG ${ }^{3}$, H. Y. ZHAO ${ }^{4}$
}

\begin{abstract}
The drainage consolidation method has been efficiently used to deal with soft ground improvement. Nowadays, it has been suggested to use a new sand soil which is a composite of sand and recycled glass waste. The permeability performance of glass-sand soil was explored to judge the feasibility of glass-sand soil backfilled in the drainage consolidation of sand-drained ground. For comparison purposes, different mix proportions of recycled glass waste, fineness modulus, and glass particle size were analyzed to certify the impact on the permeability coefficient and the degree of consolidation. The numerical results show that adding a proper amount of recycled glass waste could promote the permeability performance of glass-sand soil, and the glasssand soil drain could be consolidated more quickly than a sand drain. Experiments showed that glass-sand soil with the a $20 \%$ mix of recycled glass waste reveals the optimum performance of permeability.
\end{abstract}

Keywords: Glass-sand soil, Permeability coefficient, Mixing proportions of glass, Degree of consolidation

\section{INTRODUCTION}

A great deal of glass waste has polluted the environment, so studying its utilization in the construction field has become attractive to global architecture researchers. Craig Polley, Steven M. Crame, and Crus [1] found that glass aggregate is a satisfactory substitute for natural fine aggregate at replacement levels up to $20 \%$ of the total aggregate in concrete; Taha and Nounu [2] proposed that adding ground granulated blast-furnace slag, metakaolin, PGP, and lithium nitrate

\footnotetext{
${ }^{1}$ Prof., Shenyang Jianzhu University, School of Civil Engineering, NO.9 Hunnan East road, Hunnan District, 110168 Shenyang, China, email: cefcwang@sjzu.edu.cn

${ }^{2}$ M.E.(expected), Shenyang Jianzhu University, School of Civil Engineering, NO.9 Hunnan East road, Hunnan District, 110168 Shenyang, China, email: 847323414@qq.com

${ }^{3}$ M.E., Shenyang Jianzhu University, School of Civil Engineering, NO.9 Hunnan East road, Hunnan District, 110168 Shenyang, China, email: 516298111@qq.com

${ }^{4}$ M.E.(expected), Shenyang Jianzhu University, School of Civil Engineering, NO.9 Hunnan East road, Hunnan District, 110168 Shenyang, China, email: 837358834@qq.com
} 
$\left(\mathrm{LiNO}_{3}\right)$ can minimize the risk of the expansion of concrete through the substitution of recycled glass waste; M. M. Y. Ali and A. Arulrajah [3] indicated that potentially up to $30 \%$ of recycled crushed glass with particle size of less than $4.75 \mathrm{~mm}$ could be safely added to Class 3 recycled crushed concrete in pavement subbase applications. Glass is a material composed of amorphous silica and the main chemical composition of glass is the same as natural sand, so the chemical properties of glass are similar to those of sand; Young's modulus of glass is about 6, as sand is about 6-7; glass and sand are similar in single-grained structure and natural density. Corrosionresistant and acid-resistant glass can therefore be used in civil engineering. In addition, recycled glass waste particles are nearly the same as glass; Particles of glass are free of acute angles, and the surface of glass particles is smoother than sand, so that it is easier for glass particles to overcome friction resistance in fluid. The permeability performance of glass can be inferred to be ahead of sand through the analysis above. Soft clay foundation is widely distributed in coastal cities all over the world, and the drainage consolidation method has been a significant method for improving the permeability of soft ground [4]. Researchers present many methods to enhance the efficiency of consolidation in soft clay foundations. Zhiyong Deng and Zhiyi Zhang [5] indicated that explosive Ram in soft clay foundation can effectively accelerate and strengthen deep consolidation. Pothiraksanon and Bergado [6] performed the full-scale embankment consolidation test using prefabricated vertical thermal drains; Fei Xie and Zhandong Wang [7] suggested that plastic dewatering plates of preloading is one of the effective ways in deep soft soil; S.Horpibulsuk and A.Chinkulkijnwat [8] proposed a columnar inclusion method for improving engineering properties of soft clay ground; Najjar and Sadek [9] raised the effect of sand column inclusions on the drained response of soft clays; S. K. Tewatia, Pratima Rani Bose, and Sridharan [10] put up the fastest rapid loading methods of vertical and radial consolidations; Amiri, Esmaeily, and Mahouti [11] brought about a realistic theory of soil consolidation; W. M. Yan and T. K. Sun [12] put forward the coupled-consolidation modeling of a pile in consolidating ground. It can be predicted that good permeability performance of glass substituted for part of the soil in a drain can accelerate the drainage consolidation of the foundation. Considering the great impact on the degree of consolidation of foundation, the study on the permeability coefficient of glass-sand soil is essential to certify the feasibility of utilizing recycled glass waste as sand replacement in sand drains. 


\section{EXPERIMENT METHODOLOGY}

\subsection{Materials}

A sand specimen was made using continuous grading natural sand, with maximum nominal size of $10 \mathrm{~mm}$. Toughened glass scrap was used in this investigation. First, the recycled glass waste was crushed by a jaw crusher when the specimen was clean, pure, and dry. Then, the specimen was screened by a standard square-opening sieve with a maximum size of $5 \mathrm{~mm}$ left. Glass-sand soil was naturally dried and sieved into five particle size sections of $2.36 \sim 4.75 \mathrm{~mm}, 1.18 \sim 2.36 \mathrm{~mm}$, $0.6 \sim 1.18 \mathrm{~mm}, 0.3 \sim 0.6 \mathrm{~mm}$, and $0.15 \sim 0.3 \mathrm{~mm}$. The particle size distribution curves of the tested soil and the glass cullet is shown in Figure 1.

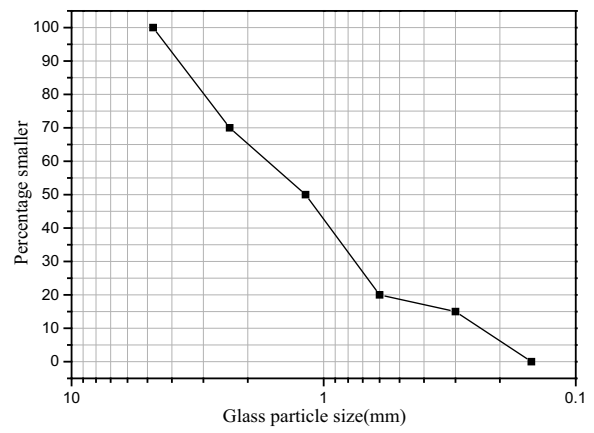

Figure 1. The particle size distribution curves of samples

All sand particle size sections were replaced by the same glass particle size sections with the substitution rate in demand. Every glass particle size sections and sand was compacted by the investigators to gain different void ratios of the specimens. Volume density and mass density of the specimens are required to calculate the void ratios of the tested sand and glass cullet, and therefore we can utilize the Archimedes principle to verify the density of the specimens. The void ratios of all particle size sections are summarized in Table 1. The mass contents of glass were set up in increments of $10 \%$, from $0 \%$ to $100 \%$, with a void ratio of 0.410 . The fineness modulus of different glass-sand soil mixes with a void ratio of 0.410 are summarized in Table 2. 
Table 1. The value of the void ratio of each particle size section

\begin{tabular}{|c|c|c|c|c|c|}
\hline Size section & $2.36 \sim 4.75$ & $1.18 \sim 2.36$ & $0.6 \sim 1.18$ & $0.3 \sim 0.6$ & $0.15 \sim 0.3$ \\
\hline \multirow{4}{*}{ Void ratio } & 0.359 & 0.376 & 0.391 & 0.410 & 0.410 \\
\cline { 2 - 6 } & 0.366 & 0.387 & 0.399 & 0.418 & 0.413 \\
\cline { 2 - 6 } & 0.373 & 0.393 & 0.410 & 0.426 & 0.424 \\
\cline { 2 - 6 } & 0.380 & 0.402 & 0.414 & 0.431 & 0.433 \\
\cline { 2 - 6 } & 0.387 & 0.410 & 0.422 & 0.439 & 0.442 \\
\hline
\end{tabular}

Table 2. Fineness modulus of different glass-sand soil mixes

\begin{tabular}{|c|c|c|c|c|c|c|c|c|}
\hline $\begin{array}{c}\text { Specimen } \\
\text { number }\end{array}$ & 1 & 2 & 3 & 4 & 5 & 6 & 7 & 8 \\
\hline $\begin{array}{c}\text { Fineness } \\
\text { modulus }\end{array}$ & 2.47 & 2.54 & 2.61 & 2.68 & 2.75 & 2.82 & 2.89 & 2.96 \\
\hline
\end{tabular}

\subsection{Proceddre}

The constant-head test [13] was used for testing the permeability of glass and sand granules. The basic laboratory test arrangement is shown in Figure 2. An ST-70 permeability meter was used in the test. The parameters of the instrument are as follows: (a) the inside diameter is $100 \mathrm{~mm}$ (b) the height of the metal cylinder is $400 \mathrm{~mm}$ (c) the distance of the piezometer is $100 \pm 0.44 \mathrm{~mm}$ (d) the height of the specimen is $10 \mathrm{~cm}$. First, we layer the specimen in the cylinder with a height of $3 \sim 4 \mathrm{~cm}$ in each layer, the same mass in each layer assures that uniformity of the specimen is preserved. Then, the clip of the infiltration pipe should be open while each layer of specimen is loaded to make water slowly penetrate the infiltration pipe. Flow should be slow to guarantee the easy emission of gas from within soil. The clip should be closed when the specimen is gradually saturated and the water level should be lower than the top of specimen. A gravel layer is loaded to the top of the specimen to avoid direct disturbance of the surface of the specimen. The distance from the top of the specimen to the top of the metal cylinder is measured to calculate the height of specimen ( $\mathrm{L}$ is the height of the metal cylinder minus the distance from the top of the specimen to the top of the metal cylinder). Then, the water supply device is closed until the water level is parallel to the 
infiltration pipe; the water level is kept steady to guarantee the permeation under constant head. The parallel of three piezometer tubes is checked after standing for a few minutes. The disposal of exhaust is needed if the three piezometer tubes aren't parallel. The regulation pipe opening is reduced to the top of specimen at the height of $1 / 3$. Water should be spilled through the infiltration pipe to guarantee the permeation under constant head. The stable water level of three piezometer tubes is recorded in order to calculate the water level differences of the piezometer tubes and the flow of water penetration in 60 s for 9 times in average. You then reduce the regulation pipe opening to the top of specimen at the middle and bottom of the $1 / 3$ and repeat the steps above. Darcy's law proposes a method to obtain the permeability coefficient of the specimen using the following formula [14]:

$$
k=\frac{Q}{\text { Ait }}
$$

Where:

$\mathrm{k}$ - the permeability coefficient of the specimen, $\mathrm{Q}$ - the total quantity of flow across time $\mathrm{t}$ $(\mathrm{t}=60 \mathrm{~s}), \mathrm{A}-$ the basal area of the specimen $\left(\mathrm{A}=78.5 \mathrm{~cm}^{3}\right), \mathrm{i}-$ the hydraulic gradient $i=\frac{\Delta H}{L}, \mathrm{~L}-$ the height of the specimen, $\Delta H$ - the average water level $\left(\Delta H=\frac{\Delta H_{1}+\Delta H_{2}}{2}, \Delta H_{1}=h_{3}-h_{2}, \Delta H_{2}=h_{2}-h_{1}\right)$.

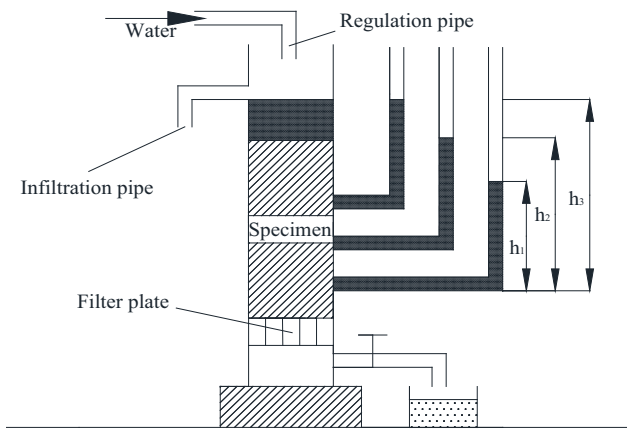

Figure 2. Parameters used for the test

\section{RESULTS AND DISCUSSION}




\subsection{PeRmeability COEFFICIENT OF GLASS-SAND SOIL AT DIFFERENT PARTICLE SIZE SECTIONS}

Figure 3 shows the comparison between the permeability coefficients of glass and sand at different particle size sections under semilog coordination. It can be seen that the permeability coefficient and the void ratio are directly related by less than one order of magnitude as the same single particle size section of glass and sand. Figure 2 also shows that the curves of the glass are superior to those of sand. This result indicates that the permeability coefficient of glass is greater than that of sand at the same void ratio; due to the fact that the larger particle size sections of specimens have a larger amount of holes, the permeability coefficient of glass-sand soil at different particle size sections differs over several orders of magnitude. It is also recognized that the permeability coefficient is low at the small particle size section.

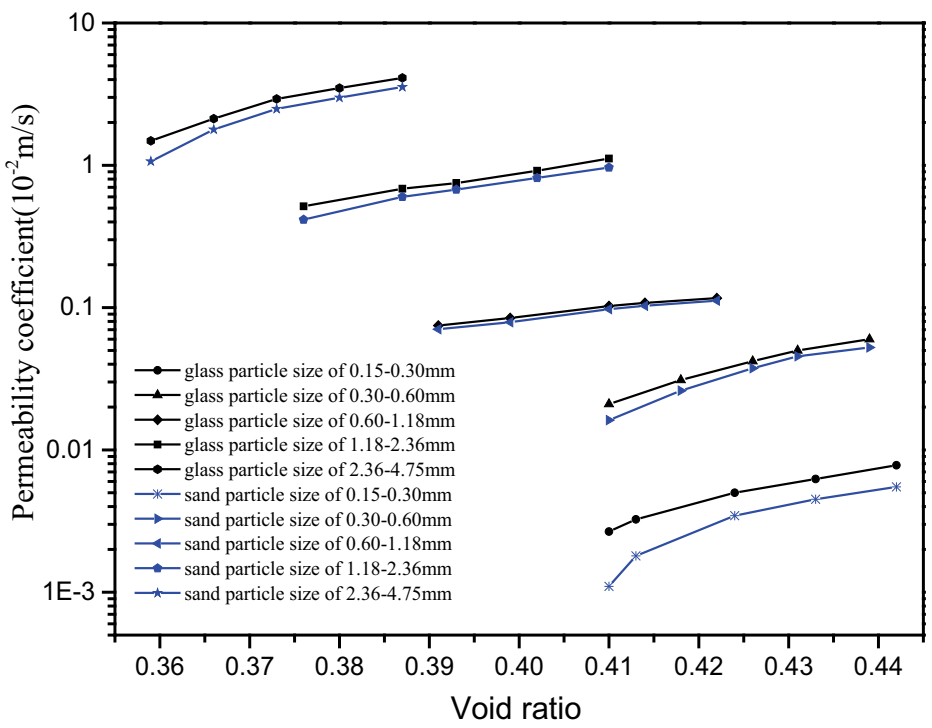

Figure 3. Permeability coefficient of glass and sand at different particle size sections 


\subsection{FACTORS OF THE PERMEABILITY COEFFICIENT OF GLASS-SAND SOIL}

\subsubsection{EFFECT OF MASS MIXING OF GLASS}

Results of mix proportion tests are shown in Figure 4 and it can be seen that the permeability coefficient of glass-sand soil is obviously increasing in comparison with the sand. The permeability coefficient of glass-sand soil increases to a point, then decreases, and then slowly increases again with the increase of the glass content. First, the permeability coefficient of glass-sand soil is increasing as the mix amount of glass varies from $0 \%$ to $20 \%$; the permeability of glass-sand soil is optimal with an increase of $60 \%$ when the glass mix amount is $20 \%$. The reasons for the result are as follows: the rate of water absorption by the glass is about $0.17 \%$ while by sand it is about $1 \% \sim 3 \%$; Also, the permeability of glass is greater than that of sand due to its smoother surface. Then, the permeability coefficient of glass-sand soil decreases, but is still greater than sand as the glass mix amount varies from $20 \%$ to $50 \%$. Finally, the permeability coefficient of glass-sand soil increases slowly as the glass mix amount varies from $50 \%$ to $100 \%$. It's obvious that the permeability of the glass is $20 \%$ greater than that of sand. Certain conclusions can be derived from the above data, mostly that a mixture of glass is beneficial to the permeability of sand.

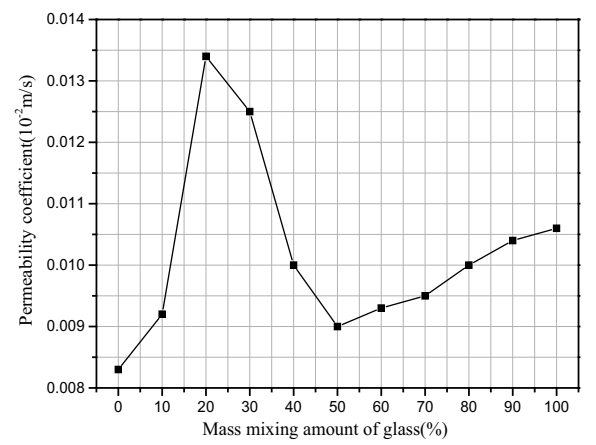

Figure 4. Permeability coefficient of glass and sand at different glass content

\subsubsection{EFFECTS OF THE VOID RATIO}

The effect of the void ratio is presented in Figure 5 with direct correlation. The permeability coefficient of glass is greater than that of sand at the same void ratio. It can be deduced that the 
shape and surface of glass particles leads to an increase in permeability. Figure 4 also shows that the permeability of the specimen is optimal with the added amount is $20 \%$.

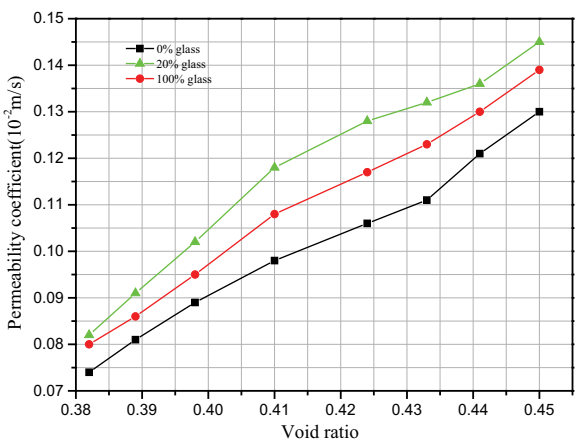

Figure 5. Relationship between void ratio and permeability coefficient

\subsubsection{EFFECTS OF THE FINENESS MODULUS}

Figure 6 shows the effect of the fineness modulus using a mix amount of $20 \%$. It is shown that the permeability coefficient of glass-sand soil increases as the fineness modulus increases. This happens because the average diameter is increased as the fineness modulus increases, which causes an expansion of the void of particles, so that flowing resistance in the void of particles will be reduced to enhance the permeability of glass-sand soil. The result of the decrease of the fineness modulus is in contrast due to the void of particles to be filled with small particle.

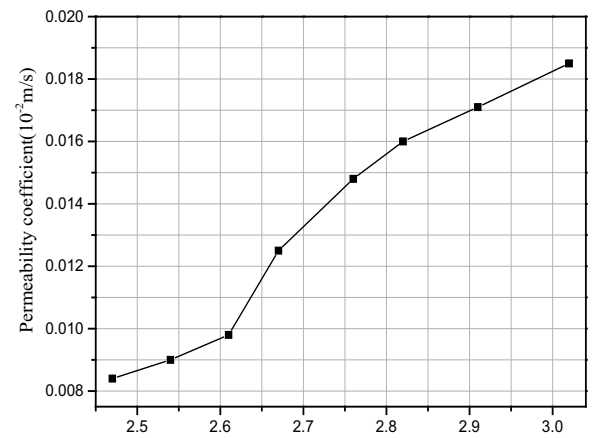

Figure 6. Permeability coefficient of glass and sand at different fineness modulus 


\subsubsection{EFFECT OF HETEROGENEOUSNESS}

Figures 7 and 8 show the particle size distribution of glass-sand soil in different uniformity and curvature coefficients. The only predictive factor for the permeability coefficient of the glass-sand soil shown in Figure 7 is the coefficient of uniformity with a void ratio of 0.389 and a curvature coefficient of 0.7. The only predictive factor for the permeability coefficient of the glass-sand soil shown in Figure 8 is the coefficient of curvature with a void ratio of 0.389 and a uniformity coefficient of 8 . Figure 9 shows that the permeability coefficient of glass-sand soil at the same void ratio and coefficient of curvature increases as the coefficient of uniformity increases. Figure 10 shows that the permeability coefficient of glass-sand soil at the same void ratio and coefficient of uniformity increases as the coefficient of curvature increases. Figures 9-10 also show that the permeability coefficient of glass-sand soil varies on the same order of magnitude.

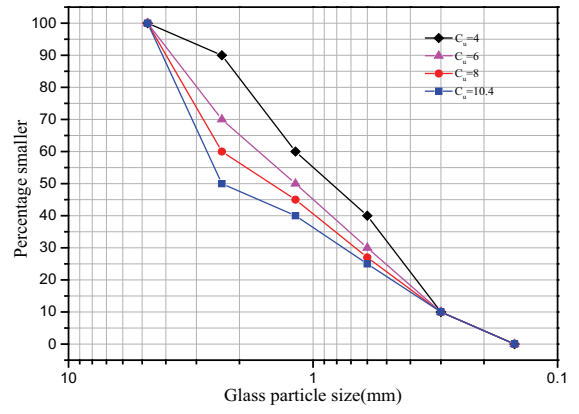

Figure 7. Particle size distribution of glass-sand soil in different uniformity coefficient

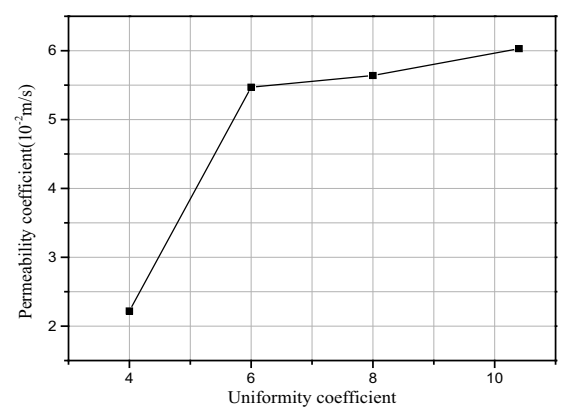

Figure 9. Permeability coefficient of glass and sand at different uniformity coefficient

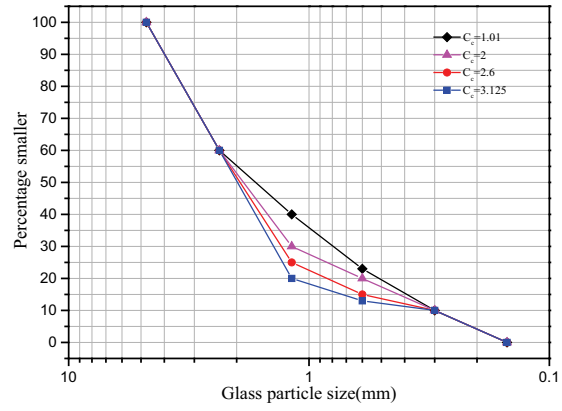

Figure 8. Particle size distribution of glass-sand soil in different curvature coefficient

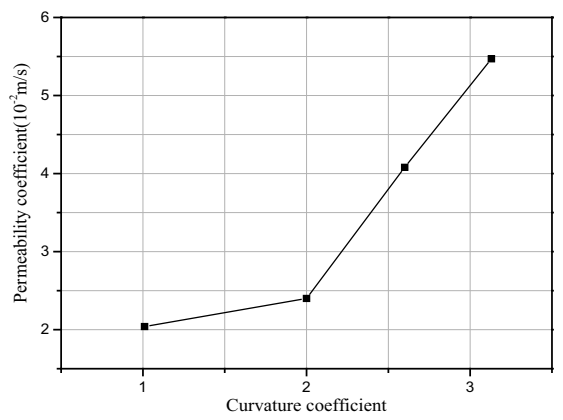

Figure 10. Permeability coefficient of glass and sand at different curvature coefficient 


\subsection{FACTORS OF CONSOLIDATION OF GLASS-SAND SOIL FOUNDATION}

The regular triangle distribution method was used in the glass-sand soil drain to treat soft ground. The layout of the glass-sand soil drain [15] is shown in Figure 11. Soft clay is assumed to be completely penetrated by the glass-sand soil drain. $d$ is the diameter of the glass-sand soil drain, 1 is the distance of the glass-sand soil drain, $\mathrm{H}$ is the length of the glass-sand soil drain, $\mathrm{r}$ is the diameter of smearing, and $\mathrm{k}_{\mathrm{h}}$ and $\mathrm{k}_{\mathrm{v}}$ are the vertical and radial permeability. The parameters above are shown in Table 3. The average degree of consolidation under the impact of drag and smearing can be obtained using the following formulas [16]:

$$
\begin{gathered}
\beta_{r z}=\frac{\pi^{2} c_{v}}{4 H^{2}}+\frac{8 c_{h}}{(F+\pi G) d_{e}^{2}} \\
F=\operatorname{In}\left(\frac{n}{S}\right)+\frac{k_{f}}{k_{s}} \operatorname{In}(S)-\frac{3}{4}
\end{gathered}
$$

$$
G=\left(\frac{k_{f}}{k_{w}}\right)\left(\frac{H}{d_{w}}\right)^{2}
$$

Where:

$\mathrm{G}$ - well resistance factor, $\mathrm{S}$ - smear ratio, which is the ratio of the diameter of smearing $\left(d_{s}\right)$ to the diameter of the effective range $\left(d_{w}\right), \mathrm{n}$ - the ratio of the diameter of the well $\left(n=\frac{d_{e}}{d_{w}}\right), k_{w}, k_{f}$ and $k_{s}-$ the permeability coefficient of sand, foundation soil and smear layer, $C_{v}$ and $C_{h}$-the horizontal and vertical consolidation coefficient. The parameters above are as follows:

$$
d_{e}=\sqrt{\frac{2 \sqrt{3}}{\pi}} \cdot l=1.05 l=1.05 \times 1.8=1.89 \mathrm{~m}
$$




$$
\begin{gathered}
n=\frac{d_{e}}{d_{w}}=\frac{1.89}{0.3}=6.3 \\
F=\operatorname{In}\left(\frac{6.3}{2}\right)+\frac{1}{2} \operatorname{In}(2)-\frac{3}{4}=0.744
\end{gathered}
$$

Table 3. Properties of the glass-sand soil drain

\begin{tabular}{|c|c|c|c|c|c|}
\hline $\mathrm{d}(\mathrm{m})$ & $1(\mathrm{~m})$ & $\mathrm{H}(\mathrm{m})$ & $\mathrm{r}(\mathrm{m})$ & $\mathrm{k}_{\mathrm{h}}(\mathrm{m} / \mathrm{s})$ & $\mathrm{k}_{\mathrm{v}}(\mathrm{m} / \mathrm{s})$ \\
\hline 0.3 & 1.8 & 15 & 0.6 & $10^{-5}$ & $10^{-4}$ \\
\hline
\end{tabular}

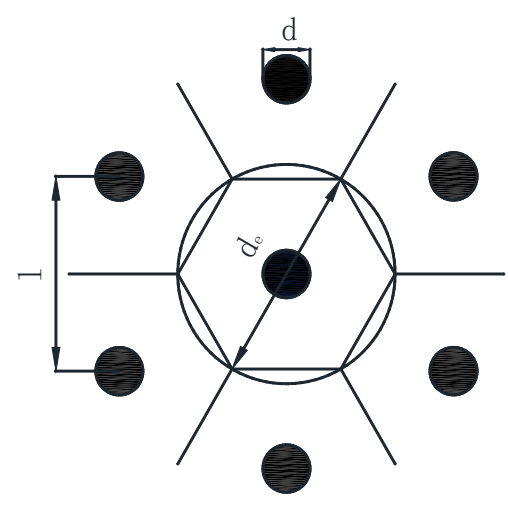

Figure 11. Layout of the glass-sand soil drain

Figure 12 shows the degree of consolidation in these factors with a time factor of 0.3 . Figure 12 also shows that the degree of consolidation is quite lumpy. The trends of the consolidation parallels with the permeability of glass-sand soil are shown to demonstrate that the mixing of glass in a sand drain can improve the degree of consolidation. 


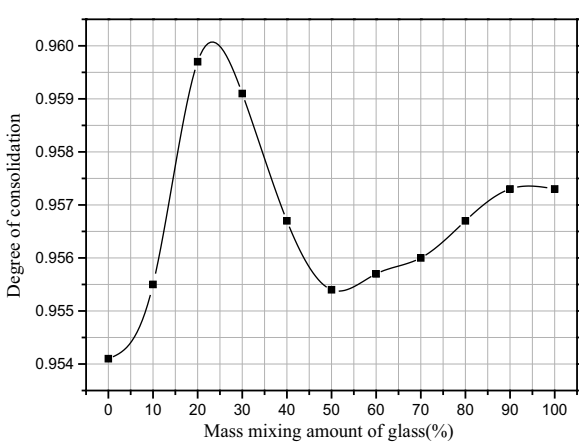

(a)

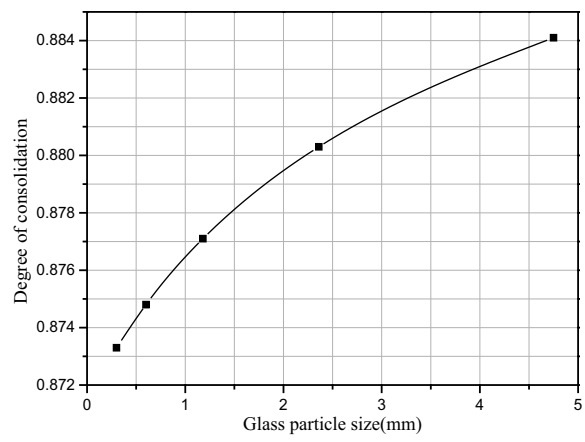

(b)

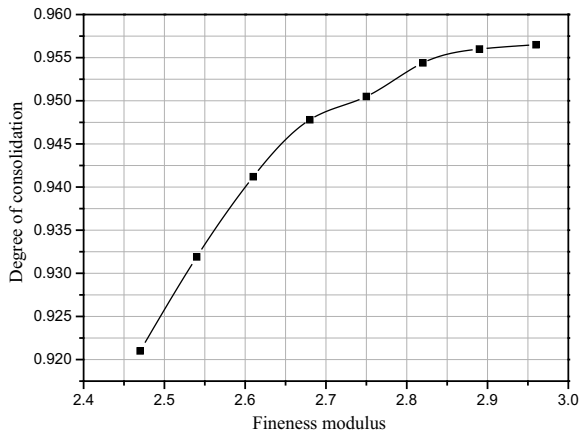

(c)

Figure 12. Effect of Consolidation of Glass-sand Soil Foundation

\section{SUMMARY AND CONCLUSIONS}

1. Glass mixtures are beneficial to the permeability of sand. The permeability coefficient of the specimen increases to a point, then decreases, and then slowly increases with the increase of the glass content. The permeability of glass-sand soil is optimal when the glass mix amount is $20 \%$.

2. The void ratio is an important factor affecting the permeability of glass-sand soil. The void of the specimen increases as the void ratio increases which causes an enhancement of permeability. 
3. The permeability coefficient of glass-sand soil increases as the fineness modulus increases and the former is the latter by 11 times.

4. Particle size distribution of glass-sand soil has a great impact on its permeability. The permeability coefficient of glass-sand soil at the same void ratio and coefficient of curvature increases on the same order of magnitude as the coefficient of uniformity; the permeability coefficient of glass-sand soil at the same void ratio and coefficient of uniformity increases on the same order of magnitude as the coefficient of curvature.

5. All factors of glass-sand soil have a great impact on the degree of consolidation. The trends of the consolidation parallels of the permeability of glass-sand soil demonstrate that the use of glass-sand soil can improve the degree of consolidation.

\section{ACKNOWLEDGEMENT}

The authors wish to thank the Program for Excellent Talents in University of Liaoning Province (LR2013026) and Liaoning BaiQianWan Talents Program (2015-57) for sponsoring this research project. 


\section{REFERENCES}

1. C. Polley, S.M. Cramer, R.V. de la Cruz, Potential for using waste glass in Portland cement concrete, Journal of Materials in Civil Engineering,10,4,210-219,1998.

2. B. Taha, G. Nounu, Utilizing waste recycled glass as sand and cement replacement in concrete, Journal of Materials in Civil Engineering,21,12,709-721,2009.

3. M.M.Y. Ali, A. Arulrajah, Potential use of recycled crushed concrete-recycled crushed glass blends in pavement subbase applications, International Geological Congress, Brisbane, Australia, 3662-3671.

4. H. Zhao, L.G. Li, The consolidation degree analysis of using load pre-pressure drainage consolidation method to consolidate soft-soil foundation, Exploration Engineering, 3, 9-11, China,2005.

5. Z.Y. Deng, Z.Y. Zhang, Innovation dynamic drainage consolidation Method by Explosive Ram in Soft Clay foundation, China Railway science, 27,6,17-21, China,2006.

6. C. Pothiraksanon, D.T. Bergado, Full-scale embankment consolidation test using prefabricated vertical thermal drains, Soil and Foundations, 50,5,599-608, Japan, 2010.

7. F. Xie, Z.D. Wang, H.Y. Xu, C. Xiao, Y.L. Jiang, S.X. Chu, Application of Plastic Dewatering Board of Preloading Method in Soft Subgrade Treatment, Chinese Journal of Underground Space and Engineering, 7,1,1542-1548, china, 2011.

8. S. Horpibulsuk, A. Chinkulkijnwat, Effect of sand column inclusions on the drained response of soft clays, International Geological Congress, Brisbane, Australia,940-947,2012.

9. S.S. Najjar, S. Sadek, M. Zakharia, S. Khalaf, Effect of sand column inclusions on the drained response of soft clays, International Geological Congress, Brisbane, Australia,4079-4088,2012.

10. S. K. Tewatia, P. R. Bose, A. Sridharan, Fastest Rapid Loading Methods of Vertical and Radial Consolidations, International Journal of Geomechanics, 13,4,332-339,2013.

11. S. N. Amiri, A. Esmaeily, A. Mahouti, A Realistic Theory of Soils Consolidation, Geological Frontiers, Dallas, Texas,3828-3837,2011.

12. W. M. Yan, T. K. Sun, coupled-consolidation modeling of a pile in consolidating ground, Journal of Geotechnical and Geoenvironmental Engineering, 138,7, 789-798,2012.

13. H.C. Wang, H. Ge, M.G. Zhou, Drain and anti-clogging ability of porous asphalt concrete based on constant head permeability experiment, Journal of Southeast University, 46,1, 209-214,2016.

14. Y.X. Zhao, H.Y. Zhang, Q.F. Lu, X.B. Liang, Experimental study of unsaturated permeability coefficient of compacted loess, Rock and Soil Mechanics,31,6,1809-1812, China,2010.

15. K. Yu, K.H. Xie, Effects of the shape of influence zone on the consolidation behavior of sand-drained ground, Engineering Mechanics, 29,1,93-98+113, china,2012.

16. D.P Xiao, H. Yang, N.Z. Xi, Effect of Smear on Radial Consolidation with Vertical Drains, Geological Frontiers, Dallas, Texas,4339-4349,2011. 


\section{LIST OF FIGURES AND TABLES:}

Fig. 1. The particle size distribution curves of samples

Rys. 1. Krzywe rozkładu wielkości cząstek próbek

Fig. 2. Parameters used for the test

Fig. 2. Parametry użyte do badania

Fig. 3. Współczynnik przepuszczalności szkła i piasku w różnych odcinkach wielkości cząstek

Fig. 3. Permeability coefficient of glass and sand at different particle size sections

Fig. 4. Współczynnik przepuszczalności szkła i piasku przy różnych zawartościach szkła

Fig. 4. Permeability coefficient of glass and sand at different glass content

Fig. 5. Relationship between void ratio and permeability coefficient

Fig. 5. Związek pomiędzy wskaźnikiem porowatości i współczynnikiem przepuszczalności

Fig. 6. Permeability coefficient of glass and sand at different fineness modulus

Fig. 6. Współczynnik przepuszczalności gleby piaszczysto-szklistej przy różnych wskaźnikach miałkości

Fig. 7. Rozkład wielkości cząstek gleby piaszczysto-szklistej przy różnych wskaźnikach różnoziarnistości

Fig. 7. Particle size distribution of glass-sand soil in different uniformity coefficient

Fig. 8. Particle size distribution of glass-sand soil in different curvature coefficient

Fig. 8. Rozkład wielkości cząstek gleby piaszczysto-szklistej przy różnych współczynnikach krzywizny

Fig. 9. Permeability coefficient of glass sand at different uniformity coefficient

Fig. 9. Współczynnik przepuszczalności szkła i piasku przy różnych wskaźnikach różnoziarnistości

Fig. 10. Permeability coefficient of glass and sand at different curvature coefficient

Fig. 10. Współczynnik przepuszczalności szkła i piasku przy różnych współczynnikach krzywizny

Fig. 11. Layout of the glass-sand soil drain

Fig. 11. Układ drenażu gleby piaszczysto-szklistej

Fig. 12. Effect of Consolidation of Glass-sand Soil Foundation

Fig. 12. Wpływ Konsolidacji Fundamentu Gleby Piaszczysto-Szklistej

Tab. 1. The value of the void ratio of each particle size section

Tab. 1. Wartość wskaźnika porowatości każdego odcinka wielkości cząstek

Tab. 2. Fineness modulus of different glass-sand soil mixes

Tab. 2. Moduł miałkości różnych gleb piaszczysto-szklistych

Tab. 3. Properties of the glass-sand soil drain

Tab. 3. Właściwości drenażu gleby piaszczysto-szklistej 


\section{BADANIE PRZEPUSZCZALNOŚCI GLEBY PIASZCZYSTO-SZKLISTEJ}

Słowa kluczowe: gleba piaszczysto-szklista, współczynnik przepuszczalności, proporcje mieszania szkła, stopień konsolidacji

\section{STRESZCZENIE:}

W pracy omówiono nową mieszaninę gleby piaszczystej, która zawiera piasek i odpady pochodzące z recyklingu szkła. Skupiono się na wskaźniku przepuszczalności gleby piaszczysto-szklistej, aby ocenić wykonalność gleby piaszczystoszklistej w konsolidacji drenażu gruntu drenowanego piaskiem. Dla celów porównawczych przeprowadzono analizę różnych ilości zmieszanych odpadów pochodzących z recyklingu szkła, wskaźnika miałkości oraz wielkości cząstek szkła, aby potwierdzić wpływ na współczynnik przepuszczalności i stopień konsolidacji. Można przewidzieć, że dobra przepuszczalność części gleby zastąpionej szkłem w odpływie może przyspieszyć konsolidację drenażu fundamentu. Opracowano próbkę piasku przy użyciu piasku naturalnego o jednorodnym gatunku, z maksymalną wielkością nominalną wynoszącą $10 \mathrm{~mm}$. W badaniu użyto pozostałości szkła laminowanego. W celu przygotowania różnych wielkości i gatunków próbek, gleba piaszczysto-szklista została naturalnie osuszona i przesiana w pięć części wielkości cząstek, tj. $2.36 \sim 4.75 \mathrm{~mm}, 1.18 \sim 2.36 \mathrm{~mm}, 0.6 \sim 1.18 \mathrm{~mm}, 0.3 \sim 0.6 \mathrm{~mm}$ i $0.15 \sim 0.3 \mathrm{~mm}$. Każdy odcinek został zastąpiony tym samym odcinkiem cząstki szkła, ze współczynnikiem zastępowalności udostępnianym na żądanie. Wszystkie odcinki wielkości cząstek szkła i piasku zostały sprasowane przez badaczy, aby uzyskać różne wartości współczynników porowatości próbek. Zawartość mieszaniny szkła została przygotowana w przyrostach $10 \%$ z $0 \%$ do $100 \%$, przy współczynniku porowatości o wartości 0.410 . Wskaźnik miałkości różnych gleb piaszczysto-szklistych został dostosowany ze współczynnikiem porowatości o wartości 0.410 . W badaniu przeprowadzono test stałej głowicy $\mathrm{i}$ użyto miernika przepuszczalności ST-70 dla dobrej przepuszczalności granulek szkła i piasku. Prawo Darcy’ego proponuje metodę uzyskania współczynnika przepuszczalności próbki, a zjawiska zostały przedstawione w następujący sposób: mieszanina szkła jest korzystna dla przepuszczalności piasku. Współczynnik przepuszczalności próbki wzrasta do pewnego punktu, a następnie maleje i ponownie powoli wzrasta wraz ze wzrostem zawartości szkła. Przepuszczalność gleby piaszczysto-szklistej jest optymalna, gdy wartość mieszaniny szkła wynosi 20\%. Współczynnik porowatości jest istotnym czynnikiem wpływającym na przepuszczalność gleby piaszczysto-szklistej. Porowatość próbki wzrasta wraz ze wzrostem współczynnika porowatości, co powoduje zwiększenie przepuszczalności. Współczynnik przepuszczalności gleby piaszczysto-szklistej wzrasta wraz ze wzrostem wskaźnika miałkości, a ten pierwszy jest większy od ostatniego o 11 razy. Rozkład wielkości cząstek gleby piaszczysto-szklistej ma ogromny wpływ na jej przepuszczalność. Współczynnik przepuszczalności gleby piaszczysto-szklistej, przy takim samym współczynniku porowatości i współczynniku krzywizny wzrasta na takim samym poziomie wielkości jak wskaźnik różnoziarnistości. Współczynnik przepuszczalności gleby piaszczysto-szklistej przy takim samym współczynniku porowatości i wskaźniku różnoziarnistości wzrasta na takim samym poziomie wielkości jak współczynnik krzywizny. Wszystkie czynniki gleby piaszczysto-szklistej mają ogromny wpływ na stopień konsolidacji. Tendencje w zakresie wartości konsolidacji przepuszczalności gleb piaszczysto-szklistych wykazują, że ich użycie może poprawić stopień konsolidacji. 